\title{
State and Citizenship in Former Communist Countries, the Albanian Case
}

\author{
Orinda Malltezi
}

\author{
Lecturer and Deputy Dean, Political Science Department, Faculty of Social Sciences, University of Tirana, Tirana, Albania
}

Email: malltezi@yahoo.com

\section{Doi:10.5901/mjss.2015.v6n2s2p165}

\begin{abstract}
The goal of this article is to establish the degree of interrelation between state and society as well as the implications that come from this interrelation by focusing on the Albanian case. If the state is perceived in relation with the society, then what comes as a result of this relationship will be seen as Plexus. On the other hand Nexus is the way the Albanian society perceives the relation between state and society, mostly represented by the functioning of state, where the state is the central axis and the society has no influence on it, this derives mostly from the political culture which has been shaped during communism. Countries that experienced totalitarian regimes tend to have similar behavior and perception towards politics which is the product of political culture. In this regard the political culture in post-totalitarian regimes shares similar elements such as: lacks of civic participation, people usually do not trust their governments or politics. The Albanian society usually does not participate in protests or other civic participations unless there is something directly related to their harm. In this regard our society behaves mostly like a post-modern society divided in various small groups of interests that are mostly incapable in achieving their aims because they lack a greater support. Although nowadays there is a greater civic participation during the transition period we lacked this participation due to some elements discussed in this paper.
\end{abstract}

Keywords: State and citizenship, state and society, relation with the society, greater civic

\section{Introduction}

The concept of "social system"1 has moved to the center of sociological theories, political theories, together with other concepts related to it, such as "social structure" and "social function" which are conceived to serve only as theoretical tools, to study the society in a given country at a given time where changes are perceived as unstructured or in other words as historical changes. In sociology state is mostly perceived as a social relationship, a rational technical or bureaucratic organization. States can be seen as places where people live and therefore influence, protest, destroy or develop. Meanwhile some sociologists see the state in relation to society; others think that the states are in fact a reflection of society representing beliefs that civil society has major influence in statehood. Our goal is to establish the degree of interrelation between state and society as well as the implications that come from this interrelation in Albania and in countries that had similar experiences. If the state is perceived in relation with the society, then what comes as a result of this relationship will be seen as PLEXUS. "PLEXUS means multiple discrete forms linked together in complex ways. On the other hand NEXUS explains a series of connections established or located in a central entity."2 Nexus is the way the Albanian society perceives the relation between state and society, mostly represented by the functioning of state, where the state is the central axis and the society has no influence on it, this comes mostly from the established Albanian political culture which has been shaped during communism. Although we should not deny that for major issues that pertain to a large extent, the reflection and reaction of the population is greater. The process of statehood did not end after the formation of the state it was not simply related to independence, or to some reform developments that lead Albanians towards some exact conclusion, statehood is a continuous process which is accompanied by ongoing structural changes. Developments are not related only to the constituent rules and institutions although they play a crucial role in achieving some objectives in relation to organization and expectations. In this regard it would be better to say that "policies" that affect the structure of the state are part of an ongoing constituent process that include a number of elements and influences coming from different sources. Weber argues that local religious cultures have shaped and are shaping organizational practices, which helped modernize practices, modern capitalism, and the modern bureaucratic

\footnotetext{
1 Parsons, T. (1951), The social system, New York, NY, USA: Free Press, pp. 575

${ }^{2}$ Carroll, P. (2006). Since, Culture and modern state formation, Berkley, and Los Angeles, California, University of California Press, pp. 3-4 
state system. In case of Albania, the religious cultures have been subject to constant changes and volatiles by failing to inculcate the bureaucracy and perhaps create an appropriate environment for anarchy in Albanian perception. Also religion was not inculcated in Albanian society being subject of various religious changes and impositions did not create a close spiritual relation to the different coexisting religions which were introduced by the greater powers. The lack of religious close relation is explained also by Edith Durham by writing that if you pass through Romania and ask them; what are you? They say Catholics, in Bulgaria they say Orthodox but in Albania they say Albanians. ${ }^{3}$

Does this mean that our society has suffered from the genesis the lack of organizational practices? This will be limited evidence as organizational forms existed in our society; it is enough to mention the existence of old statutes as a regulatory form of social relationships. Aubrey Herbert stated that Albanians are people who want mostly their freedom, they will never pay taxes. ${ }^{4}$ It is true that during the rule of Zog, who started to collect taxes regularly to all Albanians, the demonstrations of the population against taxation were limitless especially during 1923-1924, according to the journals of the time there were almost 2000 protests almost two demonstrations per hour. ${ }^{5}$ This record in the history of Albania shows that they have protested mostly because they did not want to pay the taxes because it directly damaged them although it could help develop the country, if the government appropriately used the gains. Referring to this assertion the anarchic nature of Albanians has not changed in its nature entirely, even now days the taxes are not paid by everyone but could it be true the supposition that the Albanians go to the protests only when something is related to them or when they fear a direct damage, if a policy will be undertaken? In this regard my work focuses in two main research questions which are: Does the civil society in Albania and the society in general lack civic participation in order to influence government policies? And the second research question which relates to the first one is: If there is a lack of civic participation in Albania what are the factors that are influencing mostly this behavior?

\section{Civic Participation in Albania}

In order to prove this we should look first at the number of protests that are organized in a given time and the reasons these protests are organized excluding the political gatherings or meetings as they are mainly well organized and the people that participate are related in some ways. The biggest demonstration in Albania from 1990 was the student's demonstrations that brought to the collapse of the communist regime. In the beginning of 90s Albania lacked any established and widely accepted rules of the political games, perhaps the only rule well established was the emergence and sustainability of multi-party system which was the basic element towards democracy. This unclear version of politics came after one of the most world severe dictatorship regimes. Communist regime in Albania was of no doubt the most severe regime in the region followed by Romanian communist regime that was also harsh. This regime in Albania it is often argued that "captured the person" mainly by propaganda and the induction of fear. People were not allowed to speak their mind otherwise they were imprisoned, they were not allowed even to believe in God or claiming for the bed economical situation. The regime had a direct impact on the reformation of citizen and leadership, by inducing also a certain political culture which dominates the mind and perception of Albanian people today. After 1991 there was a lack of demonstrations until 1996 and in the beginning of 1997 these demonstrations escalated to anarchy and statelessness. The protests started when the Pyramid schemes were closed after IMF stated that they were making money laundering, so they should be closed. This anarchy was not cause as a result of solidarity but as a personal need to have the money back from the Pyramid schemes. The result was not only the collapse of these pyramids but the collapse of government and the system as whole. In 1997 was an anarchy which had very tremendous results after the opening of the armory and the possession of the arsenal by the people. In this regard 1997 was not reflected as a civic resistance towards the government but as an anarchic situation that nobody wanted to experience once again. The general perception after 1990-s in Albania is that there is a lack of civic resistance, and lack of organization in our society, as we will see from the studies below. Very often the civil society has been reprimanded for supporting the governments or political parties in order to benefit from their powers. In this regard social organizations were prejudiced of fulfilling the interest of various parties and not supported even when they argue government policies. In order to understand and make an accurate observation why people are usually indifferent to the policies that are introduce from the institutions such as parliament, government, etc., I shall analyze two levels of perception, the first relates to the changing forms of governance and power

${ }^{3}$ Durham, E. M. (1905). The burden of the Balkan, London: Nelson

${ }^{4}$ Destani, B. \& Tomes, J. (2012). Miku i madh i shqiptarëve, Aubrey Herbert dhe krijimi i Shqipërisë së sotme, Via Egnatia, Tiranë, Albania

${ }^{5}$ Gazeta "Shqipëria e Re", (e diel, 18 mars 1923) , Konstancë, v.l, nr.132, pp.1 
in Albania, and the second relates to the social product which reflects the construction of the constituent structures.

\section{Power, State and Society}

It is clear that societies are composed of subsystems of different types. With subsystem we suppose any type of organization which has components related to each other such as interest groups, individuals etc. All subsystems of a society constitute "the social system" while state agencies are physical manifestations of "the social system". Various times and places reflected structures, forms, roles and functions of different states. In order to better understand the present and future of the Albanian statehood, we will look briefly at state-society relations from the Communist period until today. In this context, let us focus on a general division of states on the basis of authority and their impacts on society and vice versa:

a) Totalitarian and dictatorial states, which are characterized by higher authority, were the state intervention is limitless. The state is managing and implementing economic, social and individual activities. Dictatorship in Albania may be represents by this form of state. Communism in Albania produced intervention and the use of force produced a general fear which kept the individuals in silence. Another characteristic of communism was the propaganda introduced by the state and was mostly believed by the people that lacked the information how things were outside Albania. As Alexander Wendt states places like Albania have been called "autistic", mainly because its society had no connection to the outside world and the international system did not "construct" the state as constructivists claim. ${ }^{6}$ Communism brought to customization of society with the rules, lack of creativity, competition, lack of freedom, luck of speech etc.

b) Weak states, these states have little power and may occur during transitions. The intervention of state is limited there is high informality, free markets. Transition periods are associated with high uncertainty and informality. After communism Albania had undergo through a transition period and in some aspects and field there is still transition such as political transition. The political transition can be understood from the continuing need for consensus which does not leave space for competition. The Albanian transition like the others as well was and in some ways still is characterized by limited interferences from the government which has brought to a lot of costs coming from informality. The Albanian transition for many analysts finished in 2005 were the political rotation gave hope that a quasi democracy was established in Albania, they are not wrong but some other analysts argue that the transition is still present as there is still a lot of informality.

c) Consolidated state, these states have democratic institutions, at this stage the state has taken form, formality is increasing. The state might have balanced authority, quasi democracy. In this case the state intervention is based on the requirements of conditional priorities for governmental continuity. State at this stage of implementation formalizes rules and then integrates them into society.

An example that describes this stage may be the law of "legalizing the illegal" constructed buildings in Albania. It was thought by the politicians that the decision would meet the requirements of a great number of citizens who had built their houses illegally. At the same time we observe that the group affected by this chaos, such as the previous owners showed little resistance to change. They did not organize many protests and they did not show any willingness to continue their protest in order to be compensated more and for a shorter period, they did not try also to prevent this law to be amended. Here are some of the problems observed from this situation and obtained from the interviews with the former owners? ${ }^{7}$.

a) Owners were not organized in a stable resistance and meshed that with the onset of the problem, as a result of uncertainty surrounding the property as well as its procedure.

b) Another problem was the distrust in the institutions from the interest group which mainly believed that the resistance would not produce any solution to their problems.

c) Also the heads of the Former Owners association were dominated by the Republican party which was suppose to support them but being in coalition with the governing party did not want any trouble, so persuade the leaders of the interest groups to be silent on the matter.

d) On the other side also the interested group on legalization did not made any effort to legalize houses as they thought that this law would be proposed even by the opposition as they needed the votes of this people. Even in certain cases it is also seen as an obligation of the state to their perception.

These perceptions deriver mainly from the so called communist rule that treated property as a common property, a property for people and of nobody.

\footnotetext{
${ }_{6}^{6}$ Wendt, A., (1999), Social Theory of International Politics, New York, Cambridge, Cambridge University Press, pp. 2
}

7 the owners that possess the land before communism 
The lack of resistance in our society is due to several crucial factors: Firstly people in Albania disbelief that things can change if faced with continued resistance. This confidence comes as a result of our political culture, which is shaped after a big disappointment coming from the dictatorial regime, although lately there are some evidences that this perception is changing by inducing a change in political culture as well. The disappointments were for the most part of the population in the early 1990s, people after many great expectations and confidences coming from the regime's propaganda understood that it was almost everything a lie. After communism Albanians recognized that the communist propaganda was just an illusion. This distrust has continued and even deepened by some abortive models of resistance, which in some cases have become part of the narrow interests of certain groups.

Another belief formed and established during the communist system was that the state should take care and think about everything without asking "anything". This is another critical behavior of Albanian society which again stems from its political culture, they are used to expect from state. This perception has brought towards an "apathetic society", thinking that the state has the power and it is its duty to accomplish everything, without feeling any responsibility to change anything by giving in the end the "fault" only to public authority and to politics in general. Another legacy of the past is the fear from government which induces obedience, and in some other cases domination. The domination from government and politics has different shapes as we will see. In order to induce a change or protect our interested we need to demand that change with persistence. Balanced intervention requires useful people, active civil society, people and society should demand more from themselves and less from the state. Nietzsche states that: "The state is the coldest of all cold monsters" 8 . For Nietzsche where the state stops, begins the man who is not useless. This statement recognizes the need for useful people, which in the post-modern world seems to be the way for achieving political goals. Nowadays this perception has changed and even if the state is not perceived as Nietzsche presumes the power of people or citizens could be enormous if people are "useful" or in case of Albania if they believe in it, and act. In this regard the question that we face is: How useful are we to ourselves and to what extend does this usefulness influences government decision-making?

The answer to this question relies on three main elements of political culture that were established during dictatorial regime not only in Albania but also in the other countries that experience totalitarian regime.

The first element as mentioned above is the lack of trust that characterizes the citizens that have experience this regime, or the younger people that are influenced by the elders who experienced it. Lack of trust is manifested not only towards government but also towards other people that might represent for instance the civil society by implying a lack of civil participation at the political life. The lack of trust is manifested in different ways, some think that the best punishment towards politics is not participating in election. According to Central Election Commission in Albania known as CEC, just after communist regime in Albania there were high rate of people participation in elections. In 1991 just after the collapse 99 percent of Albanians voted, until 1996 there was only 10 percent decrease of voters participating in elections and in 1997 after the pyramidal schemes it dropped at 43 percent. ${ }^{9}$ The hopes in the beginning of 1991 had a drastic decline after the chaos of 1997 in Albania which created the idea that politics was nothing but a struggle for power. After this period it has been some irrelevant ups and downs that describe the lack of trust generally in politics. This assumption would be just speculation if we do not take into consideration the people beliefs.

In this regard we completed a questioner in Tirana where 65 percent of people did not believe in government and political parties. Another questioner in Tirana made in 2014 shows that 95 percent of people do not have trust in anything or anyone. Another poll shows that: "many types of CSOs and state organizations have the trust of only $40 \%$. However, religious organizations, charitable and other humanitarian organizations such as women's organizations have public trust as high as $60 \%{ }^{\prime \prime 10}$. Another survey made from PASOS for six countries in the Balkans shows that people in Albania, Bosnia and Herzegovina, Kosovo, Macedonia, Montenegro, and Serbia do not trust the public institutions and the political parties. For instance in Albania people believe that the institution that has the greater ability to influence the government policy is the Parliament. ${ }^{11}$ As we can see from the table below Albanians believe more in international organizations than in political parties and government.

\footnotetext{
${ }^{8}$ Nietzsche, F.W. (1976). "On the New Idol", Thus Spoke Zarathustra (Part One), in The Portable Nietzsche, tr. \& ed. by W. Kaufmann, Viking,, New York, pp.160.

${ }^{9} \mathrm{http}: / /$ liajme.parajsa.com/Politike/id_98835/

${ }^{10} \mathrm{http}: / /$ socs.civicus.org/CountryCivilSocietyProfiles/Albania.pdf

${ }^{11} \mathrm{http}$ ://pasos.org/12122/pasos-poll-citizens-of-six-balkan-countries-identify-political-parties-as-the-most-untrustworthy-institution-in-theirrespective-countries/ 


\section{Table 1:}

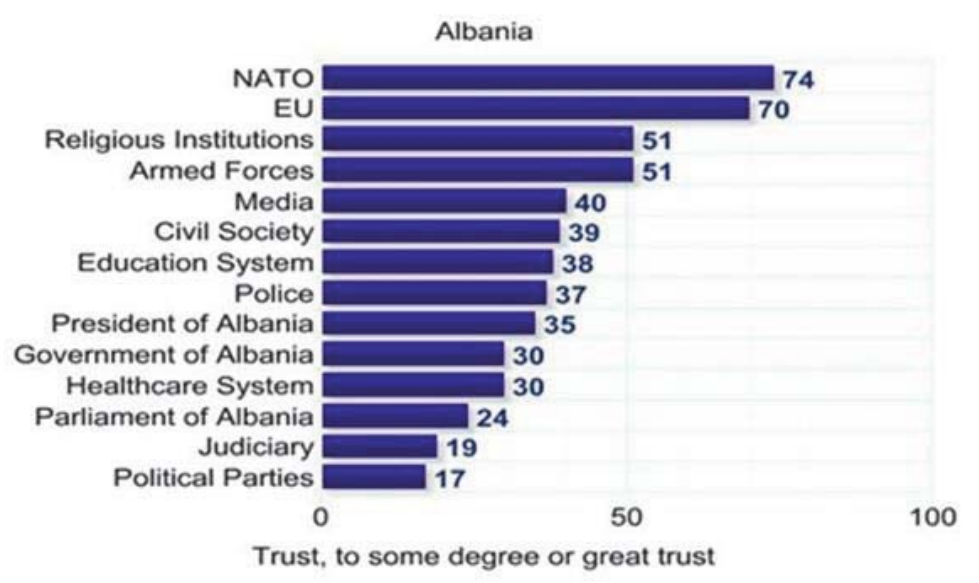

Source: Institute for Democracy and Mediation

The second element is related to the inherited fear to speak the truth, although this doesn't seem a concerning element in Albania from the general debate that generates in the media, some different reports regarding family abuse on women from different organizations such as UNICEF, UNDP, and other organizations show that a major problem is the silence of women and the lack of denunciation that comes from two main factors, the first relates to the lack of law implementation, and the second relates to the lack of substantial income of women to live alone. ${ }^{12}$ Another survey made from the Faculty of Social Sciences shows that people are afraid to complain at the directors at the working places. The repression in terms of Foucault produces silence ${ }^{13}$ he explains it through the "repressive hypothesis" where he assumes that repression continues once it has become a state of mind. In this regard he wrote: "This explains the solemnity with which one speaks of sex nowadays. When they had to allude to it, the first demographers and psychiatrists of the nineteenth century thought it advisable to excuse themselves for asking their readers to dwell on matters so trivial and base"14. Although his studies were focus on the prohibition of speaking about sex the analogy works also in regard to the prohibition of speaking once mind during communism in Albania. In this context nowadays if anyhow someone feels there might be consequences they prefer silence. But if someone has no job and not much to lose from the government policy or politics, he might be perhaps more inclined to speak against it.

The third element inherited from past is the perception that the state has the power for everything and it is responsible for everything. All the above elements induce the lack of civil participation in politics and the lack of a functional civil society. Another question in relation to this and especially to the civic participation is: Are we ready to have a liberal approach to governance or is necessary that the state intervenes in our relations in all fields? The liberal approach in this context refers to the liberal theory of international relations that presumes that the state should not intervene at the market because as Adam Smith states "the invisible hand" will regulate the market, or the market regulates itself. ${ }^{15}$ In case of Albania economically speaking citizens expect that the state should regulate the market by creating quotas for higher education which might structurally provide jobs for everybody like it was during the communist regime. In this regard our society in relation to its political culture, generally perceives that decisions should come from "above", the government must think for us while we remove all the responsibilities from ourselves. At this stage we should focus more at the Foucault's perception of power and promote this in our society as a way to enhance their participation and resistance.

\section{Power as a Product of Society}

We might conclude that political culture in Albania lacks the confidence in politics and governance. The natural question that comes from the above analyzes is: If someone does not believe in politics and government why should he expect from them?

${ }^{12}$ www.unicef.org/albania/sq/domviol-alb.pdf; www.al.undp.org

${ }^{13}$ Foucault, M., (1978), The history of Sexuality, First Volume, Random House, pp. 8-10

${ }_{14}^{14}$ Foucault, M., (1978), The history of Sexuality, First Volume, Random House, pp. 6

15 Parkin, M., (2013), Economics, 11th edition, Prentice Hall 
The expectations in the Albanian society are related to the perception formed during communism that the state owns everything, because everything was public property, and the state has also all the organizational materials and resources. This mentality embeds the idea that the state has all the powers to do whatever it aims. By thinking like this, once again most of the people in Albania do not believe in their own capabilities in changing things. From the regards above we can understand that the political culture in Albania is filled with factors that create a hesitation to resistance. Post-structuralism argues that the creation of identities, capacities and concerns that come from social groups should be seen as power. While pluralist perspective sees social groups as groups that seek to maximize their interests. ${ }^{16}$ This perception is often encountered in Albanian society where usually is believed that these groups are closely related to their interests and thus not to the product they might produce for the whole society. If we want the power to be reflected by post-structuralism terms then we must also examine the concept of power.

According to Foucault Power is equal to Product. Foucault does not see the power in state institutions, but weighs "Power" in the details of social practices to the point where it produces effects. ${ }^{17}$ Pluralism and power are exercised in endless ways, for Foucault they are not driven by politics or by a single project but rather from systematic and numerous projects. According to Foucault all social relations and identities produce power while the product is not always helpful or nice, even Foucault criticizes the way power is used in society because the concept of power suggests that during its exercise there will be dominance. Dominance comes from the hierarchy that is present everywhere in society, even in a small group like family. In this context, Foucault says: "Power is everywhere, not because it embraces everything, but because it comes from everywhere"18.

Product as a result of the exercise of power would be helpful if we had resistance.

Government acts only to those who resist Foucault says while government institutions are only one aspect of governing strategy. Another aspect of governance is the new forms of politics in contemporary societies. "Foucault defines "government" as "the conduct of conduct", the attempt to influence the action of free subjects"19. In this context, the behavior of the society might determine the government behavior as well, in case they act as free subjects by resisting to inconvenient power of authority. Thus the society can guide the behavior of its governments the same way they try to influence them. If the exercise of power will cause dominance then how can we overcome this challenge? Foucault believes that discourse as a new form of exercise of power in modern societies is a good power to resist domination. It requires knowledge of multiple discourses in order to argue thoughts and suggest the best alternatives. In this context, discourse contributes to the organization's performance by improving institutions, these institutions are considered as non - discursive because their primary purpose is not discourse but service. Exercise promotes institutional practices or performance and produces discourse.

In this context the Albanian society relations that are dominated by government and are not subject to resistance is likely to give an unprofitable distorted product. While the "free subject" those that are not dominated by government might consequently become instruments of political parties or of the government. On the other hand the "free subject" that is not an instrument to any party might use discourse to improve the functioning of institutions. These may include academics, civil societies, who are not immune from possible instrumentation. Therefore required with broad participation of society and interest groups, as the increase in quality and quantity through discourse as a result of increased public awareness of the discourse itself, would complicate the instrumentalization and domination, prompting more representative politics and therefore good. In case of Albania this article shows that our society has shown a lack of resistance and a lack of trust, as resistance cases are seen as instruments of political parties or small interest groups thus not fighting for the implementation of just policies. I argue that this has been mostly a consequence which relates and derives from the forms of governance and political culture described above. The events of 1997 which developed as a result of income loss of people involved in pyramid schemes showed a disorganized revolt and resistance creating initially an uncertain situation and fear in the population as a result of the anarchy created. The creation of the anarchic situation did not bring any solution to the problem but it resulted only in overthrowing the government. Although resistance existed, it failed its initial intent to return the money from pyramid schemes or government but had the consequences of early elections and anarchy. Pyramid schemes came as a result of the application of liberal economy which relies on the idea that the market regulates itself while another element that favored the situation was the weak Albanian state in the post - communist period, according to the above classification. In this context the resistance of Albanians seems to be present only when they are affected directly but not as a gesture of solidarism with a group of people. While the state characteristics are

${ }^{16}$ Nash, K., (2000), Contemporary Political Sociology, Massachusetts USA, Blackwell, pp. 14

${ }^{17}$ Ibid, pp. 20-27

${ }^{18} \mathrm{lbid}, \mathrm{pp} .23$

19 Ibid, pp. 25 
closely related to the behavior of society we can see that the movement of the Albanian state from a weak state to a state with democratic consolidated institutions begins in 2005 when the rotation of government after the election was mainly accepted from the political parties. Consolidation of democratic institutions took another dimension, showing that the ongoing political transition phase was about to end in 2013 elections, as the next rotation was without any dispute and accusation of manipulation. These developments increased the confidence of society in politics by believing that the period of manipulation and lies had come to an end. Increase citizens' confidence shows a change in attitude and mindset of the political culture which has reduced mistrust in institutions.

By early 2013 it was still believed that resistance and organization of the Albanian society was absent but the news for the arrival of Syrian chemical weapons for demolition in Albania, threatened the Albanians. The threat that Albania might become a place for chemical weapons demolition and this might have terrible impact to the health of people made the resistance toward the government policy very persistent and massive engagement of the youth. The protests begin on Nov. 8, 2013 and after a week the resistance won the battle by influencing the government policy in not accepting the Syrian weapons. What happened can be explained by the Foucault's perception on power.

According to Foucault any troubles should be articulated with words and arguments. Foucault assumes that power relations reproduce themselves deep in society there is no such thing as the opposition between the state and civil society. There is a central conflict, but a plurality of mobile fights. If this claim of Foucault would count as true for Albania then a major challenge is raising, that of citizen to be more participatory in politics or policy compositions, through resistance becoming more responsible and believing that their resistance will bring the change they want. This resistance had also the support of the opposition as well but without taking any meritocracy. Although the developments in the protest showed a lack of organization where some pioneering organizations were not having a central organization, which caused clashes between organizers in terms of meritocracy and the desire to run, however, the determination of the resistance and durability united the society by providing the requested product.

\section{Conclusions}

This article presumed that the lack of civic participation is a characteristic of post-communist countries and more generally of post-authoritarian states as they share some similar elements which compose the lack of this participation such as: people do not believe that their behavior or opposition to some policies will consequently change government's policies, they fear the consequences that might follow as they are not "free subjects", people do not trust civil society as they believe that their organizations and actions have hidden agenda, and mostly they are pushed by their immediate interest which does not represent people's interest in general. Driven from the studies of political culture I presume that there is a connection between countries that experience government repression for a long time as they tend to have similar behavior although the study expresses this connection it does not explore further experiences to make this a comparative study but helps to develop similar articles with similar cases. The aim of the article is to give answers on the existence of the lack of civic participation in Albania and try to provide continuous solutions to these believes and behaviors.

We can say that the Albanian society on this issue showed that in fact Foucault is right when he states that the state is the "the conduct of conduct" 20 and as a result the state will seek the guidance but the society can push the government to change many elements of its guide. Ernesto Laclau and Chantal Mouffe think: "Everything is cultural" and therefore social order is constructed, challenged and reproduced by culture.21 In this context if people believe that together they can act as "free subjects" with no fears and they can change unpleasant situation and policies than the impact on government policies will be of no doubt present no matter to what extend this influence will be. Previous theories of political sociology view society as a unified unit, while post-modernism sees culture and society fragmented, indecisive and unstable. Post-modern thinking on how the economy and the politics are highly dependent on culture, and if culture is undecided the discourse may then bring to an improvement of social structures and functions entirely. The discourse if well articulated and argued could influence politics. In conclusion, not only the discourse but also resistance to government's policies should promote the desirable policies that contribute to the greater benefit of society. Any concern should be articulated and argued by constantly resisting to power. Unless efforts are ongoing we cannot say that there is resistance and therefore if this product is local resistance and without impacts then we have no reason to complain about the government policy as long as we have not sought or resisted against anything.

20 Ibid, pp. 25

${ }^{21}$ Ibid, pp. 25 


\section{References}

Group of Authors, Akademia Shqiptare e Shkencave, (2002), Historia e Popullit Shqiptar, Toena, Tiranë, Albania

Destani, Bejtulla, Jason Tomes, (2012), Miku i madh i shqiptarëve, Aubrey Herbert dhe krijimi i Shqipërisë së sotme, Via Egnatia, Tiranë ,Albania

Dragoj, Nuri, (2010), "Shqiptarët dhe Grekët", wesso, Tirana, Albania, pp. 363

Durham, Edith, M., (1905), The burden of the Balkan, London: Nelson

Carroll, Patrick, (2006), "Science, Culture, and Modern State Formation", Berkley, and Los Angeles, California, University of California Press

Foucault, Michel, (April 25 1995), Discipline and Punish, The Birth of the Prison, Vintage Books; 2nd edition

Foucault, Michel, (1978), The history of Sexuality, First Volume, Random House

Foucault, Michel, (1980), Power/Knowledge, Pantheon Books, New York

Foucault, M., (1986), The Foucault Reader. P. Rabinow (ed.). Harmondsworth: Penguin

Giddens, Anthony, (1984), The Constitution of Society. Cambridge: Polity

Giddens, A., (1985), The Nation State and Violence: Volume Two of A Contemporary

Critique of Historical Materialism, Cambridge: Polity

Glenny, Misha. (2000), The Balkans 1804-1999: Nationalism, War and the Great Powers, Granta Books, London

Hanlon, Querine, (2011), State Actors in the 21st Century Security Environment, National Strategy Information Center

Information-Processing, Journal of Communication Volume 46, vëllimi 3, 1996

Kaehne, Axel, (2007), Political and Social Thought in Post-Communist Russia, London, New York, Routledge

Laclau, Ernesto, (2005), The Populist Reason, London: Verso

Laszlo, Alexander and Krippner, Stanley, (1998), Systems Theories: Their Origins, Foundations, and Development, J.S. Jordan (Ed.), Amsterdam: Elsevier Science

Nash, Kate, (2000), Contemporary Political Sociology, Blackwell, Massachusetts USA

Mouffe, Chantal, (1993), The Return of the Political, London: Verso

Parkin, Michael, Economics, $5^{\text {th }}$ Edition, Addison-Wesley, 1999

Parkin, Michael, Economics, 11 $11^{\text {th }}$ edition, Prentice Hall, 2013

Parsons, Talcott, (1951), The social system, New York, NY, SHBA: Free Press, f. 575

Rapoport, Anatol, (1968), General system theory, The international encyclopedia of social sciences, 15, f 452-458. David L. Sills (ed.). New York: Macmillan \& The Free Press

Rose, Nikolas and Miller, Peter, (Jun. 1992), "Political Power beyond the State: Problematics of Government", The British Journal of Sociology, Wiley-Blackwell, Vol. 43, No. 2, pp. 173-205

Gazeta, SHQIPËRIA E RE, Konstancë, v.l, nr.132. e diel, 18 mars 1923, p.1

Way, Baldwin M., UCLA, and Roger D. Masters, (1996), Emotion and Cognition in Political, Dartmouth College

Weber, Max, and Baehr, Peter R., Wells, Gordon C., (2002), The Protestant ethic and the "spirit" of capitalism and other writings. Penguin

Wendt, A., (1999), Social Theory of International Politics, New York, Cambridge, Cambridge University Press

Weick, Karl E., Middle Range Theories of Social Systems, Behavioral Science Volume 19, issue 6, pp. 357-367

Web

www.unicef.org/albania/sq/domviol-alb.pdf

www.al.undp.org

http://socs.civicus.org/CountryCivilSocietyProfiles/Albania.pdf

http://pasos.org/12122/pasos-poll-citizens-of-six-balkan-countries-identify-political-parties-as-the-most-untrustworthy-institution-in-theirrespective-countries/

http://lajme.parajsa.com/Politike/id_98835/ 